\title{
Isolation and Identification of Cellulolytic Bacteria from the Gut of Three Phytophagus Insect Species
}

\author{
Rajib Kumar Shil ${ }^{1}$, Suman Mojumder ${ }^{1}$, Faozia Faleha Sadida ${ }^{2}$, Myn Uddin ${ }^{2}$ and \\ Dwaipayan Sikdar ${ }^{1 *}$ \\ ${ }^{1}$ Department of Biochemistry and Molecular Biology; ${ }^{2}$ Department of Microbiology; University of Chittagong; \\ Chittagong - Bangladesh
}

\begin{abstract}
The cellulolytic bacteria from the gut of three different phytophagous insects were studied to isolate novel cellulolytic organism for biofuel industry. Among the threse, gut of $\mathrm{P}$. quatuordecimpunctata larvae contained both highest no of total bacterial count $\left(6.8 \times 10^{7} \mathrm{CFU} / \mathrm{gut}\right)$ and cellulolytic bacteria $\left(5.42 \times 10^{3} \mathrm{CFU} / \mathrm{gut}\right)$. Fifteen different isolates were obtained from the gut of $\mathrm{O}$. velox, A. miliaris and $\mathrm{P}$. quatuordecimpunctata. All the isolates produced clear zone in CMC medium staining with Congo red. The isolates included Gram positive Enterococcus, Microbacterium and Gram negative Aeromonas, Erwinia, Serretia, Flavobacterium, Acenitobacter, Klebsiella, Yersinia, Xenorhabdus, Psedomonas and Photorhabdus. Out of the fifteen isolated and identified bacterial species, twelve bacterial species were novel being reported for first time as having cellulase activity.
\end{abstract}

Key words: Gut bactéria, cellulolytic, $O$. velox, A. miliaris, $P$. quatuordecimpunctata

\section{INTRODUCTION}

The demand for fuel is increasing with the advancement of civilization. But dependence solely on fossil fuel is causing the depletion of its stock rapidly. Moreover, fossil fuel is not environment friendly. As a result, alternative source of fuel or renewable energy is the demand of present day. The production of bioethanol has been tried in different countries from food kernel and other starchy materials (Schubert 2006; Lin and Tanaka 2006) which causes increased food price. Lignocellulosic plant biomass that is abundant in nature has been considered an attractive alternative source of ethanolic biofuel that mitigate global worming, reduce competition for food and ensure economic sustainability (Lynd et al. 1991; Lynd et al. 2008). Cellulose of plants can be converted to constituent glucose by cellulase system and this glucose could be fermented to ethanol (Wyman 1999; Hamelinck et al. 2005).

Conversion of lignocellulosic materials into glucose by enzymatic method is a costly process (Wyman 1999; Wyman 2007). It has been suggested that reducing cellulase enzyme by half decreases the processing cost up to $13 \%$ (Lynd et al. 2008). Current limitations of enzymatic degradation of lignocellulosic biomass are mostly related to enzymatic stability, low specific activity and susceptibility to inhibitory agents or byproducts (Mousdale 2008; Kristensen et al. 2009). To make the process cost effective, efficient cellulase are being haunted (Oppert et al. 2010). Insects are very efficient in converting the plant materials into glucose with their highly efficient gut systems that can truly be considered

*Author for correspondence: sikdardw@yahoo.com 
as highly efficient natural bioreactors (Sun and Scharf 2010).

Cellulolytic activity has been reported in the gut fluids in different insect species belonging to ten insect orders (Watanabe and Tokuda 2001; Willis et al. 2010). The cellulase activity of these insects is historically attributed to symbiotic gut microorganisms. Herbivorous insects often rely on microbes in their guts to digest plant materials such as cellulose and lignin (Weibing et al. 2013). Hence, the guts of insects could be a potential source of microorganisms with novel cellulolytic activities for biofuel production.

The study on gut microbes of insects with cellulolytic activities is limited. The aims of this investigation was to isolate and identify novel cellulolytic bacteria for industrial use from three different phytophagous insect guts namely $O$. velox belonging to order orthoptera and $P$. quatuordecimpunctata and A. miliaris both belonging to order coleoptera.

\section{MATERIALS AND METHODS}

\section{Insects and Gut Fluids Collection}

$O$. velox at nymphal stage and larvae of $A$. miliaris and $P$. quatuordecimpunctata were collected from the leaves of infested host plants during April-June at midday from Fatickchari upozilla, Chittagong, Bangladesh. Until dissection, insects were kept on the plant host tissues. Five of each type of insect (nymph/larvae) were selected for dissection when they were actively feeding. After immobilizing on ice for around half an hour, the insects were surface sterilized by submersion in $70 \%$ ethanol for $1 \mathrm{~min}$ and rinsed in sterile water before dissection. Insects were dissected in $0.9 \% \mathrm{NaCl}$ using dissection scissors and fine-tipped forceps to remove the intact entire guts. The guts of same insects were transferred to $1.5 \mathrm{~mL}$ centrifuge tubes containing $0.5 \mathrm{~mL} 0.9 \% \mathrm{NaCl}$, homogenized and vortexed with medium speed for $2 \mathrm{~min}$ to separate the microbial cells from the gut wall. All gut extractions were performed in a sterile ventilation hood on the same day of collection.

\section{Enumeration of Total Microbes and Cellulolytic Microbes}

The microbes present in the guts were enumerated by serial dilution of macerated guts of three insects with sterile water in two solid media using $10 \mu \mathrm{L}$ of preparation. One medium (lysogenic broth agar plate) contained $10 \mathrm{~g}$ peptone, $5 \mathrm{~g}$ yeast extract, 5 $\mathrm{g} \mathrm{NaCl}, 20 \mathrm{~g}$ agar and $1 \mathrm{~L}$ distilled water (this medium was used for total microbial count) (Bertani 2003). The other medium (CMC agar plate) contained $2.5 \mathrm{~g} \mathrm{NaNO}_{3}, 0.2 \mathrm{~g} \mathrm{MgSO}_{4}, 0.2 \mathrm{~g}$ $\mathrm{NaCl}, 0.1 \mathrm{~g} \mathrm{CaCl}_{2} \cdot 6 \mathrm{H}_{2} \mathrm{O}, 20 \mathrm{~g}$ agar, $1 \mathrm{~g} \mathrm{CMC}$ and $1 \mathrm{~L}$ distilled water (this medium was used for the count of cellulolytic microbes). The lysogenic broth agar plates and CMC plates were incubated at $37^{\circ} \mathrm{C}$ for overnight and until colonies were visible, respectively. The total viable count of cultivatable total microbes and cellulolytic microbes were expressed as the number of colony forming unit (CFU/gut).

\section{Isolation of Cellulolytic Microbes through Filter Paper Digestion}

The macerated guts of each insect were inoculated in $5 \mathrm{~mL}$ of basal salt media $\left(2.5 \mathrm{~g} \mathrm{NaNO}_{3}, 0.2 \mathrm{~g}\right.$ $\mathrm{MgSO}_{4}, 0.2 \mathrm{~g} \mathrm{NaCl}, 0.1 \mathrm{~g} \mathrm{CaCl}_{2} \cdot 6 \mathrm{H}_{2} \mathrm{O}$ in a liter water) containing filter paper $(5$ pieces of Whatman filter paper no.1, each of $5 \mathrm{mg}$ and area $0.49 \mathrm{~cm}^{2}$ ) for isolating the cellulolytic microorganisms. A control was prepared with basal salt media and 5 pieces of Whatman filter paper but no gut extract for checking the degradation/disappearance of filter paper. The tubes were incubated aerobically and shaken at $180 \mathrm{rpm}$ at $37^{\circ} \mathrm{C}$ in a shaker incubator. After the filter paper was visibly degraded, indicating the presence of cellulases, or after 4-6 wk (whichever came first), serial dilutions of the cultures $(10 \mu \mathrm{L}$ of each) were transferred to solid medium (CMC agar plate). As a control, a single agar plate from each culture preparation was opened in the UV laminar flow hood for $15 \mathrm{~min}$. This was done to check the contamination from within the hood. All the plates were incubated at $37^{\circ} \mathrm{C}$ until colonies were visible.

\section{Screening of Microbes for Cellulolytic Potential} Bacterial colonies seemed to be different based on the colony size, shape and color found in the CMC plate for total count of cellulolytic bacteria or for the isolation of bacteria capable of filter paper digestion were transferred to two sets of CMC plates by tooth pick -one for identification of isolates and other for examining their cellulolytic potential using the Congo-Red overlay method (Teather and Wood 1982). For the Congo-Red method, plates were flooded with $0.1 \%$ Congo red (Sigma-Aldrich) for 10-15 min before de-staining with $1 \mathrm{M} \mathrm{NaCl}$ solution for $15-20 \mathrm{~min}$ for several 
times or until the clear zones around the colonies were visualized. Colonies showing discoloration of Congo red were taken as positive cellulosedegrading microbial colonies.

Identification of Potential Cellulolytic Microbes Microbes, which produced clear zones, were identified based on the cultural, morphological and biochemical characteristics and using Bergey's Manual of Systemic Bacteriology (Buchanan and Gibbons 1974; Holt et al. 1984).

\section{RESULTS AND DISCUSSION}

\section{Total bacterial count and count of cellulolytic bacteria}

The total bacterial count and count of cellulolytic bacteria in three insect guts are shown in Table 1. The total bacterial count and total cellulolytic bacterial count were highest in $P$. quatuordecimpunctata. In $O$. velox gut, $0.01 \%$ of total bacteria were cellulolytic whereas it was 0.002 and $0.008 \%$ for A.miliaris and $P$. quatuordecimpunctata, respectively. The total no of bacteria in the insect gut larvae varied. Grasshopper Zonocerus variegates contained bacterial count 13-90x10 ${ }^{5}$ (Ademolu and Idowu 2011) whereas total bacterial count of B. mori was $6.08 \pm 3.08 \times 10^{11}$ (Anand et al. 2010). The cellulolytic bacterial count varied from insect to insect. Bacterial count with CMCase activity in the hindgut of $H$. parallela was $1.14 \pm 0.13 \times 10^{8}$ (Huang et al. 2012) whereas population density of cellulolytic bacteria in $S$. vistita ranged from $2.4 \times 10^{5}$ to $3.6 \times 10^{6} \mathrm{CFU} / \mathrm{gut}$ (Delalibera et al. 2005). In this study, the bacterial count in different gut segments (foregut, midgut and hindgut) of larvae was not quantified. In many insect larvae, most of the cellulolytic bacteria are present in the hindgut (Huang et al. 2012) and the exogenous cellulolytic enzymes are localized to the insect hindgut (Oppert et al. 2010).

Table 1 - Total bacterial count and cellulolytic bacterial count of three insect guts.

\begin{tabular}{|c|c|c|}
\hline $\begin{array}{l}\text { Name of } \\
\text { insect }\end{array}$ & $\begin{array}{l}\text { Total bacterial } \\
\text { count (CFU/gut) }\end{array}$ & $\begin{array}{c}\text { Total cellulolytic } \\
\text { bactéria(CFU/gut) }\end{array}$ \\
\hline O. velox & $3.1 \times 10^{7}$ & $3.2 \times 10^{3}$ \\
\hline A.miliaris & $1.65 \times 10^{7}$ & $3.7 \times 10^{2}$ \\
\hline P. quatuord & unctata $6.8 \times 10^{7}$ & $5.42 \times 10^{3}$ \\
\hline
\end{tabular}

\section{Identification of cellulolytic microbes}

Microbial colonies grown on CMC plate directly from the insect guts or after enrichment in filter paper were selected for the identification based on their size, shape, color and other visual characteristics as well as investigated by the physical and biochemical methods (Table 2) for identification. Out of the nineteen colonies, fifteen isolates were identified that represented twelve different genera. The isolates from $O$. velox were Photorhabdus luminescens, Enterococcus faecalis, Enterococcus durans, Flavobacterium odoratum, Serretia marcescens and Serretia entomophila. Isolates identified from $P$. quatuordecimpunctata were Erwinia ananus, Aeromonas salmonicida, Enterococcus casseliflavus and Acinetobacter calcoaceticus whereas five different species Klebsiella oxytoca, Microbacterium imperiale, Yersinia pestis, Xenorhabdus poinari and Pseudomonas saccharophila were identified from A. miliaris (Table 3). Although different bacterial species were identified from different insect gut in this study but it did not indicate that they did not contain any common bacterial species. Actually, the purpose of this study was to isolate different cellulolytic bacteria from different insect guts. Hence, the isolates were selected on their variability in three insect guts as a whole not to encompass total bacterial community in every individual insect gut. The bacterial isolates were clustered into seven different phyla (Table 3).

Out of fifteen isolates, seven namely Enterococcus faecalis, Serretia marcescens, Acenatobacter calcoaceticus, Erwinia ananus, Aeromonas salmonicida, Klebsiella oxytoca and Pseudomonas saccharophila were capable of growing on filter paper. All the fifteen isolates of three insect guts produced zone of clearance when grown on CMC plates and stained with Congo red (Fig. 1). The isolates were incubated for different time period to produce the zone of clearance. Hence, the hydrolytic value of the isolates was not compared. Some of the species found in this study were previously reported as cellulase producers. $S$. marcescens isolated from soil exhibited cellulase activity (Sethi et al. 2013). E. casseliflavus/ gallinarum species isolated from buffalo's and horse's cecum and buffalo's colon were able to degrade lignin, xylan and cellulose, respectively (Wahyudi et al. 2010). Y. pestis, pathogenic to human and other animals, has also been reported as cellulase producer (uniport data bank). 
Table 2 - Physiological and biochemical characteristics of isolated bacterial strains.

\begin{tabular}{|c|c|c|c|c|c|c|c|c|c|c|c|c|c|c|c|}
\hline \multirow{2}{*}{$\begin{array}{l}\text { Characteristic } \\
\text { Features }\end{array}$} & \multicolumn{15}{|c|}{ Isolate's ID } \\
\hline & OV1 & OV2 & OV3 & OV4 & OV5 & OV6 & PQ1 & PQ2 & PQ3 & PQ4 & AM1 & AM2 & AM3 & AM4 & AM5 \\
\hline Gram stain & - & + & + & - & - & - & - & - & + & - & - & + & - & - & - \\
\hline Morphology & $\mathrm{R}$ & $\mathrm{C}$ & $\mathrm{C}$ & $\mathrm{R}$ & $\mathrm{R}$ & $\mathrm{R}$ & $\mathrm{R}$ & $\mathrm{R}$ & $\mathrm{C}$ & $\mathrm{R}$ & $\mathrm{R}$ & $\mathrm{R}$ & $\mathrm{R}$ & $\mathrm{R}$ & $\mathrm{R}$ \\
\hline Spores & - & - & - & - & & & & & - & & & & & & \\
\hline Motility & + & - & - & - & + & + & + & - & + & + & - & + & - & + & + \\
\hline Pigmentation & $\mathrm{Y}$ & - & - & - & - & - & $\mathrm{Y}$ & - & $\mathrm{Y}$ & - & Ro & - & - & $\mathrm{Br}$ & Ro \\
\hline $\begin{array}{l}\text { Oxygen } \\
\text { relation }\end{array}$ & $\mathrm{F}$ & $\mathrm{F}$ & $\mathrm{F}$ & A & $\mathrm{F}$ & $\mathrm{F}$ & $\mathrm{F}$ & $\mathrm{F}$ & $\mathrm{F}$ & A & $\mathrm{F}$ & A & $\mathrm{F}$ & $\mathrm{F}$ & $\mathrm{A}$ \\
\hline Catalase & + & - & - & + & ND & ND & + & + & - & + & + & + & + & - & + \\
\hline Oxidase & - & ND & ND & + & ND & ND & - & + & ND & - & - & ND & - & - & + \\
\hline Urease & - & ND & ND & + & - & - & - & - & ND & ND & + & ND & - & - & ND \\
\hline Methyl red test & - & ND & ND & ND & - & + & ND & ND & ND & ND & ND & ND & + & - & ND \\
\hline VP test & - & ND & + & ND & + & + & ND & + & + & ND & + & ND & - & - & ND \\
\hline Indole test & + & ND & ND & - & - & - & + & ND & ND & ND & + & ND & - & - & ND \\
\hline $\begin{array}{l}\text { Nitrate } \\
\text { reduction }\end{array}$ & - & - & + & - & + & + & - & + & + & ND & + & - & + & - & ND \\
\hline $\begin{array}{l}\mathrm{H}_{2} \mathrm{~S} \text { production } \\
\text { Hydrolysis of }\end{array}$ & - & ND & - & ND & - & - & ND & ND & - & ND & - & - & - & - & ND \\
\hline Starch & ND & ND & ND & - & ND & ND & ND & ND & ND & ND & ND & ND & ND & ND & + \\
\hline Gelatin & ND & ND & ND & + & + & + & + & + & ND & - & - & ND & ND & ND & - \\
\hline $\begin{array}{l}\text { Citrate } \\
\text { utilization }\end{array}$ & - & ND & ND & ND & + & + & ND & ND & ND & + & + & ND & - & - & ND \\
\hline $\begin{array}{l}\text { Acid from } \\
\text { glucose }\end{array}$ & + & - & ND & + & + & + & + & + & ND & + & + & - & - & + & - \\
\hline $\begin{array}{l}\text { Gas from } \\
\text { glucose }\end{array}$ & ND & ND & ND & ND & ND & ND & ND & + & ND & + & + & ND & ND & ND & ND \\
\hline Acid from & & & & & & & & & & & & & & & \\
\hline Arabinose & + & ND & ND & + & - & - & + & ND & ND & + & + & + & + & - & + \\
\hline Lactose & + & + & + & + & - & - & + & + & + & + & + & - & & - & - \\
\hline Maltose & + & ND & ND & ND & + & ND & + & + & ND & + & + & - & + & - & - \\
\hline Mannitol & ND & ND & - & + & + & ND & + & + & + & + & + & - & + & - & - \\
\hline Raffinose & + & - & - & ND & ND & ND & + & + & + & + & + & - & - & - & - \\
\hline Rhamnose & + & ND & ND & + & - & - & + & ND & ND & + & + & ND & - & - & ND \\
\hline Xylose & + & - & - & + & - & - & + & + & + & + & + & + & + & + & + \\
\hline Sucrose & + & + & - & + & + & - & + & + & + & + & + & + & - & + & + \\
\hline
\end{tabular}

OV - O. velox, PQ - P. quatuordecimpunctata, AM - A. Miliaris, R - Rod shaped, C - Coccoid, Y - Yellow, Br - Brownish, Ro - Red orange, F Facultative anaerobic, A - Aerobic, + Positive and - Negative, ND - Not done

Table 3 - Different bacterial isolates from three phytophagous insect guts.

\begin{tabular}{lll}
\hline Family/Phylum & Name of the isolate & $\begin{array}{c}\text { Isolate's } \\
\text { ID }\end{array}$ \\
\hline Enterobacteriaceae & $\begin{array}{l}\text { Photorhabdus luminescens } \\
\text { Xenorhabdus poinari }\end{array}$ & OV1 \\
& Erwinia ananus & PQ1 \\
& Klebsiella oxytoca & AM1 \\
& Yersinia pestis & AM3 \\
& Serretia marcescens & OV5 \\
& Serretia entomophila & OV6 \\
Pseudomonadaceae & Pseudomonas saccharophila & AM5 \\
Enterococcaceae & Enterococcus faecalis & OV2 \\
& Enterococcus durans & OV3 \\
& Enterococcus casseliflavus & PQ3 \\
Vibrionaceae & Aeromonas salmonicida & PQ2 \\
Micrococcaceae & Microbacterium imperiale & AM2 \\
Neisseriaceae & Acinetobacter calcoaceticus & PQ4 \\
Flavobacteriaceae & Flavobacterium odoratum & OV4 \\
\hline
\end{tabular}

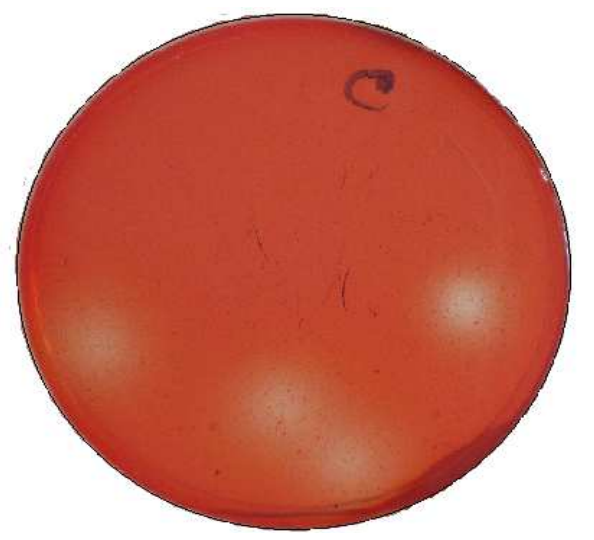

Figure 1 - Zone of clearance shown by the isolates in CMC plate 
Although other species of bacteria isolated from the insect guts in this study were not reported as cellulase producers but many of their genera have been reported as cellulase producers. Several bacteria isolated from the soil have been reported as cellulose producer such as $F$. johnsoniae (Lednicka et al. 2000), Pseudomonas mendocina (Lednicka et al. 2000) and also from the gut of scrab H. parallela (P. nitroreducens) (Huang et al. 2012). Enterococcus sp was found in both insects, $O$. velox and $P$. quatuordecimpunctata. Members of the genus Enterococcus are among the most common gut bacteria detected in larval guts across a diversity of insect orders (Martin and Mundt 1972), including Diptera (Ahmad et al. 2006; Toth et al. 2006; Cox and Gilmore 2007) and Lepidoptera (Inglis et al. 2000; Broderick et al. 2004). Along with other genera, the bacterial community associated with larvae and adults of $D$. velon gut are dominated by members of the genera Acinetobacter, Erwinia, Serratia (MoralesJiménez et al. 2009). Cellulase activity was also reported in Acinetobacter anitratus (Ekperigin 2007). Acinetobacter lwoffi and Microbacterium paraoxydans were found in the gut of Ostrinia nubilalis (Lepidoptera) and genus Acinetobacter sp and Klebsiella sp were found in the gut of Leptinotarsa decemlineata (Coleoptera). All the isolates showed cellulolytic activity (Velanova et al. 2012). Cellulolytic activity was also shown by Microbacterium present in the gut of $H$. parallela (Huang et al. 2012).

\section{CONCLUSION}

To the best of our knowledge, except Serratia marcescens, Enterococcus casseliflavus and Yersinia pestis, all other twelve species Photorhabdus luminescens, Enterococcus faecalis, Enterococcus durans, Flavobacterium odoratum, Serretia entomophila, Erwinia ananus, Aeromonas salmonicida, Acinetobacter calcoaceticus, Klebsiella oxytoca, Microbacterium imperiale, Xenorhabdus poinari and Pseudomonas saccharophila isolated from the guts of three insect specimen are reported first time as cellulase producers. They may be source of novel cellulase enzymes. However, quantitative analysis and characterization of the cellulase produced by these species will justify their use in biofuel and other cellulase based industries.

\section{ACKNOWLEDGEMENTS}

This work was supported by a grant from the Ministry of Science and Technology, Government of Bangladesh.

\section{REFERENCES}

Ademolu KO, Idowu AB. Occurrence and Distribution of Microflora in the Gut Regions of the Variegated Grasshopper Zonocerus variegatus (Orthoptera: Pyrgomorphidae) during Development. Zool Stud. 2011; 50(4): 409-415.

Ahmad A, Broce A, Zurek L. Evaluation of significance of bacteria in larval development of Cochliomyia macellaria (Diptera: Calliphoridae). J Med Entomol. 2006; 43: 1129-1133.

Anand AAP, Vennison SJ, Sankar SG, Probhu DIG, Vasan PT, Raghuraman $\mathrm{T}$, et al. Isolation and characterization of bacteria from the gut of Bombyx mori that degrade cellulose, xylan, pectin and starch and their impact on digestion. J Insect Sci. 2010; 10: 107.

Bertani G. Lysogeny at mid-twentieth century: P1, P2, and other experimental systems. J Bacteriol. 2003; 186: 595-600.

Broderick NA, Raffa KF, Goodman RM, Handelsman J. Census of the bacterial community of the gypsy moth larval midgut by using culturing and cultureindependent methods. Appl Environ Microbiol. 2004; 70: 293-300.

Buchanan RE, Gibbons NE. Bergey's Manual of Determinative Bacteriology. 8th ed. Baltimore: Williams and Wilkins; 1974; p.1268.

Cox CR, Gilmore MS. Native microbial colonization of Drosophila melanogaster and its use as a model of Enterococcus faecalis pathogenesis. Infect Immun. 2007; 75: 1565-1576.

Delalibera I, Handelsman J, Raffa KF. Contrasts in cellulolyic activities of gut microorganisms between the wood borer, Saperda vestita (Coleoptera: Cerambycidae)and the bark beetles Ips pini and Dendroctonus frontalis (Coloptera:Curculionidae). Environ Entomol. 2005; 34(3): 541-547.

Ekperigin MM. Preliminary studies of cellulase production by Acinetobacter anitratus and Branhamella sp, African J Biotechnol. 2007; 6(1): 28-33.

Hamelinck CN, van Hooijdonk G, Faaij APC. Ethanol from lignocellulosic biomass: Techno economic performance in short-, middle- and long-term. Biomass Bioenergy. 2005; 28: 384-410.

Holt JG, Krieg NR, Sneath PHA, Staley JT, Williams ST. Bergey's Manual of Determinative Bacteriology. 9th ed. Baltimore: Williams \& Wilkins; 1994; p.786. 
Huang S, Sheng $\mathrm{P}$, Zhang $\mathrm{H}$. Isolation and identification of cellulolytic bacteria from the gut of Holotrochia parallela larvae (Coleoptera: Scarabaeidae). Int J Mol Sci. 2012; 13: 2563-2577

Inglis GD, Lawrence AM, Davis FM. Pathogens associated with southwestern corn borers and southern corn stalk borers (Lepidoptera: Crambidae). J Econ Entomol. 2000; 93: 1619-1626.

Kristensen JB, Felby C, Jorgensen H. Yielddetermining factors in high-solids enzymatic hydrolysis of lignocellulose. Biotechnol Biofuels. 2009; 2, 11.

Lednicka D, Mergaert J, Cnockaert MC, Swings, J. Isolation and identification of cellulolytic bacteria involved in the degradation of natural cellulosic fibres. Syst Appl Microbiol. 2000; 23(2): 292-299.

Lin Y, Tanaka S. Ethanol fermentation from biomass resources: current state and prospects. Appl Microbiol Biotechnol. 2006; 69(6): 627-642.

Lynd LR, Laser MS, Bransby D, Dale BE, Davison B, Hamilton R, et al. How biotech can transform biofuels. Nature Biotechnol. 2008; 26: 169-172.

Lynd LR, Cushman JH, Nichols RJ, Wyman CE. Fuel ethanol from cellulosic biomass. Science. 1991; 251: 1318-1323.

Martin JD, Mundt JO. Enterococci in insects. Appl Microbiol. 1972; 24: 575-580.

Morales-Jiménez J, Zúñiga G, Villa-Tanaca L, Hernández-Rodríguez C. Bacterial community and nitrogen fixation in the red turpentine beetle, Dendroctonus valens LeConte (Coleoptera: Curculionidiae:Scolytinae). Microb Ecol. 2009; 58(4): 879-891.

Mousdale DM. Biofuels: Biotechnology, Chemistry, and Sustainable Development. Boca Raton, FL: CRC Press; 2008; p. 66-78.

Oppert C, Klingeman WE, Willis JD, Oppert B. Prospecting for cellulolytic activity in insect digestive fluids. Comp Biochem Physiol B Biochem Mol Biol. 2010; 155: 145-154.

Schubert C. Can biofuels finally take center stage? Nature Biotechnol. 2006; 24(7): 777-784.

Sethi S, Datta A, Gupta BL, Gupta S. Optimization of Cellulase Production from Bacteria Isolated from Soil. ISRN Biotechnol. 2013: 1-7.
Sun JZ, Scharf ME. Exploring and integrating cellulolytic systems of insects to advance biofuel technology. Insect Sci. 2010; 17: 163-165.

Teather RM, Wood PJ. Use of Congo redpolysaccharide interactions in enumeration and characterization of cellulolytic bacteria from the bovine rumen. Appl Environ Microbiol. 1982; 43: 777-780.

Toth EM, Hell E, Kovacs G, Borsodi AK, Marialigeti $\mathrm{K}$. Bacteria isolated from the different developmental stages and larval organs of the obligate parasitic fly, Wohlfahrtia magnifica (Diptera: Sarcophagidae). Microb Ecol. 2006; 51: 13-21.

Velanova C, Marco G, Domı́nguez-Escriba' L, Genove's S, Sentandreu V, Bataller E, et al. Bacteria from acidic to strongly alkaline insect midguts : Potential sources of extreme cellulolytic enzymes. Biomass Bioenergy. 2012; 45: 288-294).

Wahyudi A, Cahyanto MN, Soejono M, Bachruddin Z. Potency of lignocellulose degrading bacteria isolated from buffalo and horse gastrointestinal tract and elephant dung for feed fiber degradation. $J$ Indonesian Trop Anim Agric. 2010; 35(1): 34-41.

Watanabe H, Tokuda G. Animal cellulases. Cell Mol Life Sci. 2001; 58: 1167-1178.

Weibing S, Shangxian X, Xueyan C, Su S, Xin Z, Lantao L, et al. Comparative Genomic Analysis of the Endosymbionts of Herbivorous Insects Reveals Eco-Environmental Adaptations: Biotechnology Applications. PLoS Genet. 2013; 9(1):1-12.

Willis, JD, Oppert C, Jurat-Fuentes JL. Methods for discovery and characterization of cellulolytic enzymes from insects. Insect Sci. 2010; 17: 184-198.

Wyman CE. What is (and is not) vital to advancing cellulosic ethanol. Trends Biotechnol. 2007; 25: 153157.

Wyman CE. Biomass ethanol: technical progress, opportunities, and commercial challenges. Ann Rev Energy Environ. 1999; 24: 189-226.

Received: November 29, 2013; Accepted: April 24, 2014. 